\title{
A Case of Biphenotypic Sinonasal Sarcoma Found in a Young Woman's Nasal Cavity
}

\author{
Young Gun Kim ${ }^{1}$, Jae Won Heo ${ }^{1}$, Woo Yong Bae ${ }^{1} \mathbb{D}$, and Song-Hee Han ${ }^{2}$ \\ Departments of ${ }^{1}$ Otorhinolaryngology-Head and Neck Surgery and ${ }^{2}$ Pathology, College of Medicine, Dong-A University, Busan, Korea
}

\author{
젊은 여성의 비강 내에서 발견된 Biphenotypic Sinonasal Sarcoma 1예 \\ 김영근 ${ }^{1} \cdot$ 허재원 $^{1} \cdot$ 배우용 $^{1} \cdot$ 한송희 $^{2}$ \\ 동아대학교 의과대학 ${ }^{1}$ 이비인후과학교실, ${ }^{2}$ 병리학교실
}

\author{
Received January 13, 2021 \\ Revised April 2, 2021 \\ Accepted April 14, 2021 \\ Address for correspondence \\ Woo Yong Bae, MD, PhD \\ Department of Otorhinolaryngology- \\ Head and Neck Surgery, \\ College of Medicine, \\ Dong-A University, \\ 26 Daesingongwon-ro, Seo-gu, \\ Busan 49201, Korea \\ Tel $+82-51-240-5428$ \\ Fax +82-51-253-0712 \\ E-mail doncamel@dau.ac.kr
}

Biphenotypic sinonasal sarcoma (BSNS) is a newly recognized, very rare malignant tumor of nose and paranasal sinuses, which usually occurs in women. This tumor contains both neural and muscle tissue in the tumor tissue. It is an invasive disease occuring locally in the nasal cavity. However, if not found early, it can spread along the facial structure, for instance, the orbit, skull base, intracranium, and the oropharynx. This tumor is an uncommon disease that has not been reported in Korea to date. We report a case of a 35-year-old female recently diagnosed with BSNS with a review of the literature.

Korean J Otorhinolaryngol-Head Neck Surg 2022;65(1):55-61

Keywords Biphenotypic; Nasal neoplasm; Paranasal sinus; Sarcoma; Spindle cell.

\section{서 론}

육종(sarcoma)은 중간엽조직에서 기원한 결합조직, 뼈, 근 육 등으로부터 기원한 악성종양이다. 이중표현형 비부비동 육 종(biphenotypic sinonasal sarcoma, BSNS)은 신경조직과 근육조직을 함께 포함하는 발생적 특징을 가지며 비강 구조 내에서 형성되는 악성 종양으로, 현재까지 국내에 보고된 바 가 없다. ${ }^{1,2)}$ 이는 주로 여성에서 발생하고 비강 및 부비동 내 에서 국소적으로 발생하나 조기에 발견되지 않으면 안면의 구조를 따라서 퍼질 수 있는 침습적인 질환이다. ${ }^{3)}$

저자들은 비폐색과 비출혈을 주소로 내원한 35 세 여성 환 자에서 $\mathrm{BSNS}$ 를 진단하고 치험하였기에 문헌 고찰과 함께 보 고하는 바이다.

This is an Open Access article distributed under the terms of the Creative Commons Attribution Non-Commercial License (https://creativecommons.org/licenses/by-nc/4.0) which permits unrestricted non-commercial use, distribution, and reproduction in any medium, provided the original work is properly cited.

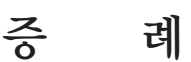

35세 여성이 2개월 정도의 좌측 비폐색을 주소로 외래에 내원하였다. 환자는 비증상 외 다른 증상은 없었으며 그 외 과거력, 가족력, 직업력상 특이한 사항은 없었다. 내원 당시 시행한 비강 내시경 검사상 비중격 편위가 보이고 편위된 중 격 뒤쪽에 비인두 종괴가 확인되었다(Fig. 1).

부비동 전산화단층촬영 결과, 좌측 비강에 $3 \mathrm{~cm}$ 크기의 경 계가 명확한 조영 증강된 종괴가 관찰되었다(Fig. 2). 전산화 단층촬영상 종괴는 좌측 비강을 채우고 두개저부나 안와, 상 악동을 침범하지 않은 양상을 보였다. 또한 혈관이 과다분포 된 모습을 나타내어 혈관섬유종(angiofibroma) 또는 고립성 섬유종(solitary fibrous tumor)이 의심되어 비부비동 자기공 명영상을 시행하였다. 비부비동 자기공명영상 $\mathrm{T} 2$ 강조영상에 서 종괴는 전산화단층촬영에서 나타난 범위 이상의 침범을 보이지 않으며 저강도 신호와 고강도 신호가 불규칙하게 배 
열된 상태로 전반적인 저강도 신호를 보였고(Fig. $3 \mathrm{~A}$ and B), $\mathrm{T} 1$ 강조영상에서 조영증강 소견이 보이지 않았다(Fig. $3 \mathrm{C}$ and $\mathrm{D})$. 일반적으로 혈관섬유종이나 고립성 섬유종은 $\mathrm{T} 1$ 에서 동 등 또는 저강도 신호강도를 보이고, T2에서 저신호강도 및
고신호강도의 불규칙한 배열이 나타나게 되고, 본 증례 또한 혈관 섬유종 또는 고립성 섬유종으로 의심되어 혈관조영술을 시행하기로 하였다.

촬영 예정일 전, 환자는 수 시간 지속된 비출혈을 주소로
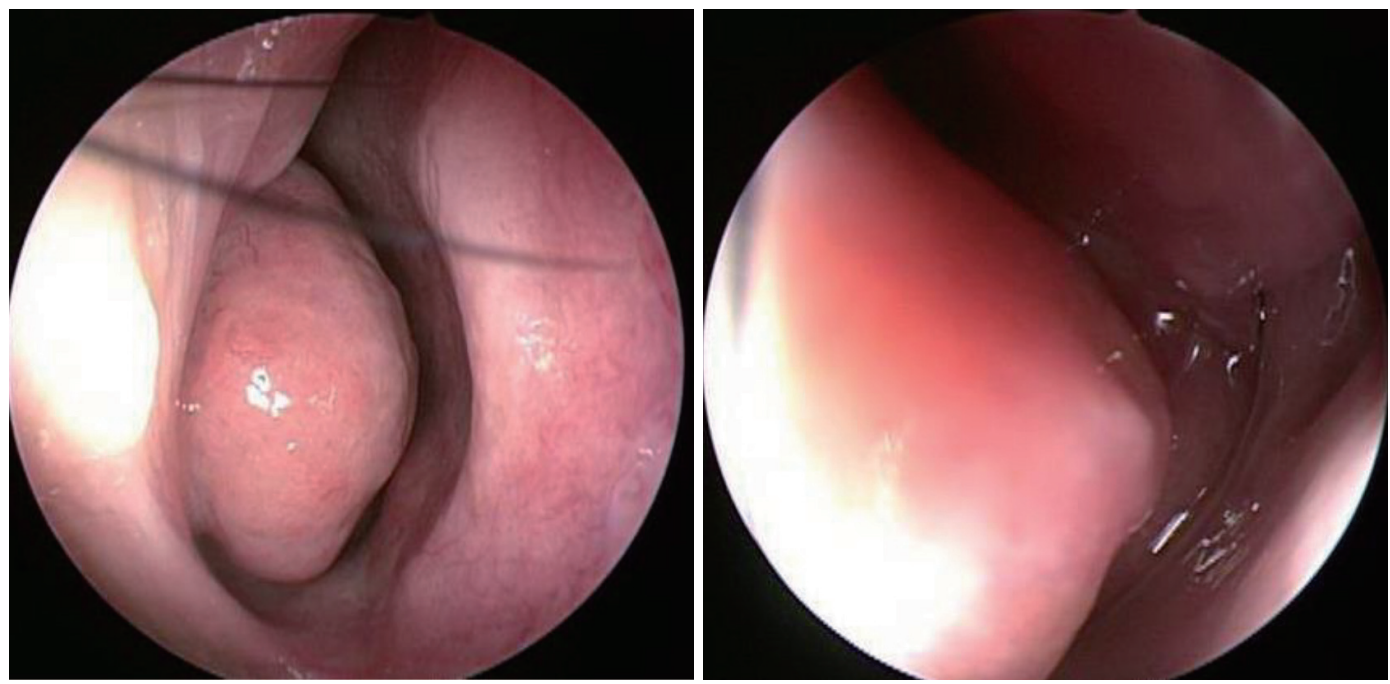

Fig. 1. Endoscopic exam. Preoperative nasal endoscopic findings at left nasal cavity.
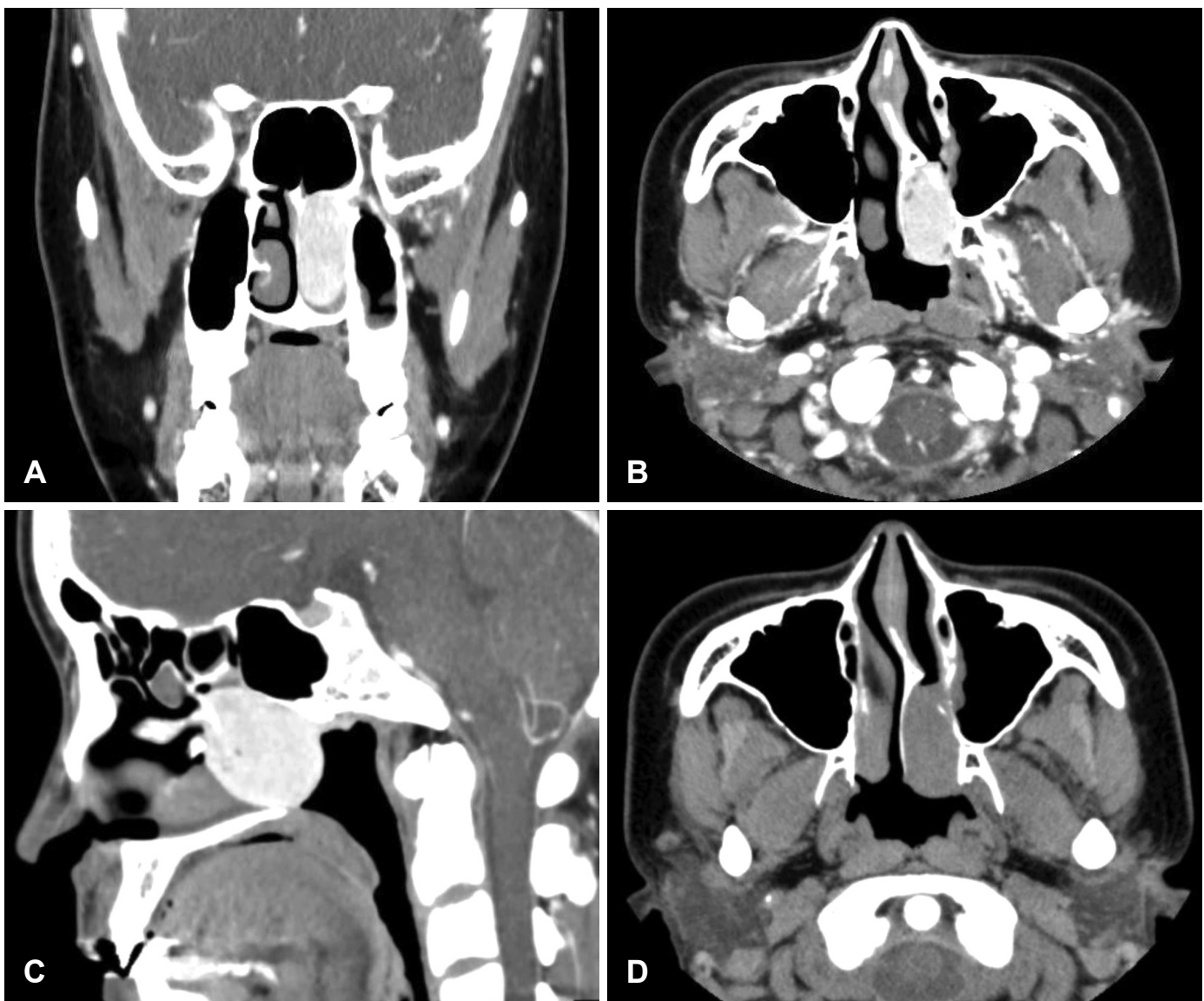

Fig. 2. Preoperative radiologic findings. CT findings. Hypervascular mass at left posterior nasal cavity. Axial view (A), coronal view (B), saggital view $(C)$, and non-enhanced view (D). 

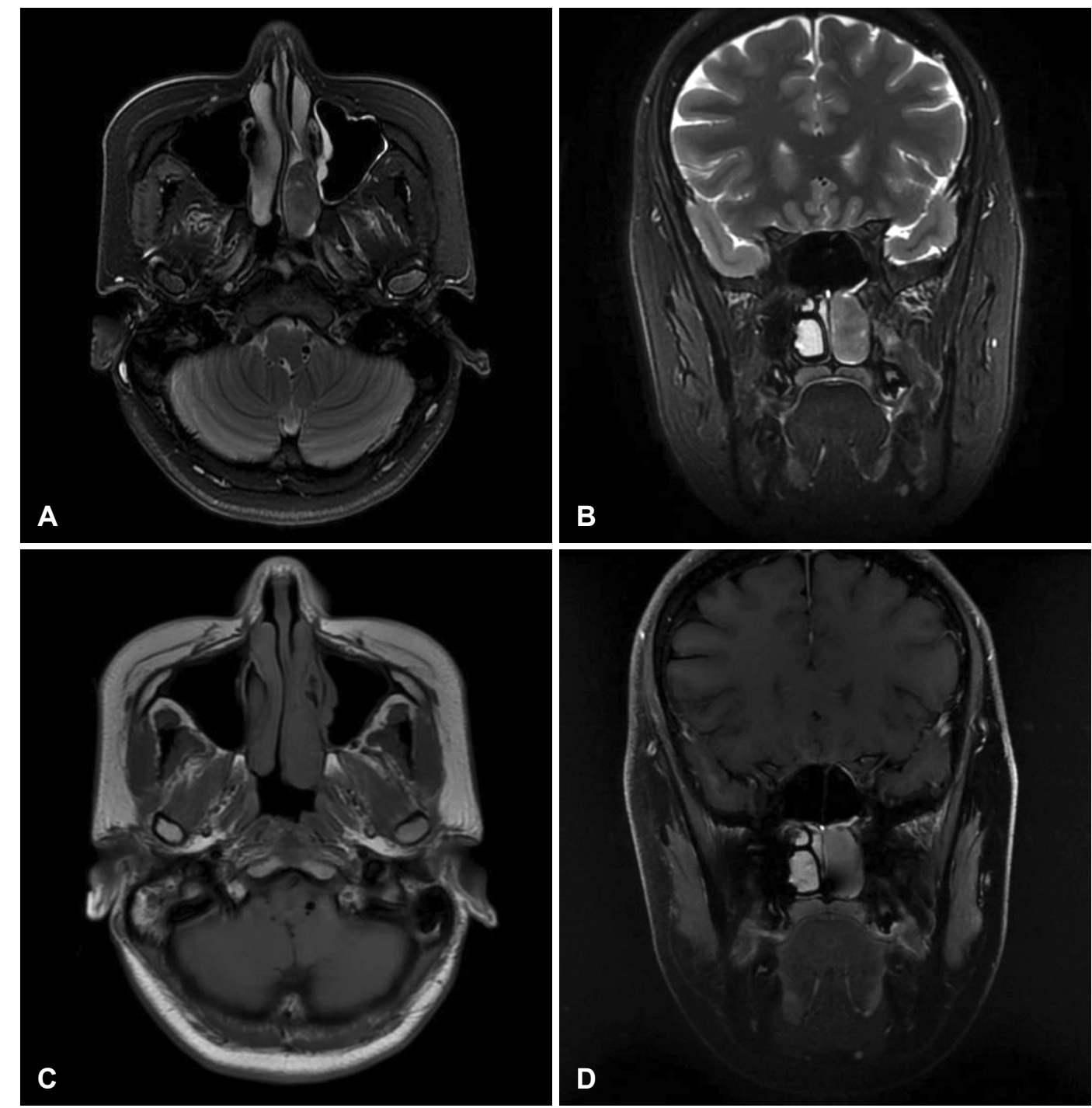

Fig. 3. Preoperative radiologic findings. MRI findings. T2 axial view (A), T2 coronal view (B), T1 axial view (C), and T1 coronal view (D).

응급실을 통해 내원하여 응급 혈관조영술을 시행하였으며, 바 깥목동맥(external carotid artery)에서 기원하는 영양동맥인 좌측 내측 상악동맥(left internal maxillary artery)을 polyvinyl alcohol을 이용하여 색전술을 시행하였다(Fig. 4). 색전 술을 통해 출혈이 조절된 하루 뒤, 전신마취하 수술을 시행 하였다. 먼저 비중격 교정술을 하여 왼쪽의 비강 내 종양을 확인 후, 중비갑개를 일부 제거한 후 종양의 경계를 확인하였 고, 후비강의 나비입천장 오목(sphenopalatine fossa)에 종양 의 뿌리(stalk)를 확인하였다. 종양은 주변 조직과의 유착은 없었으며, 이를 완전 제거 후 양극성 소작기(bipolar electrocauterizer)로 출혈을 조절하고 종양을 제거한 경계부분을 소 작하였다. 술전 색전술을 시행하였기에 출혈의 양은 많지 않 았다. 적출된 종양은 육안적으로 핑크색의 종괴였고 크기는 $31 \times 15 \times 24 \mathrm{~mm}$ 였다. 병리조직학적 소견상 비강 점막의 간질
내로 방추형세포(spindle cell)가 높은 세포 밀도로 증식하면 서 침윤하는 모습이 관찰되었다. 방추형세포의 핵염색질은 균 질하며 핵소체도 관찰되지 않고 면역조직화학염색을 통해서 방추형 세포가 neural marker인 S-100 protein과 myogenic marker인 smooth muscle actin (SMA)을 동시에 보인다는 것을 확인할 수가 있었다(Fig. 5). 환자는 현미경학적 소견과 면역조직화학염색 소견으로 BSNS로 최종 진단되었다.

환자의 수술 후 입원기간 동안 비출혈 및 안구증상이나 다 른 합병증은 없었으며, 퇴원 후 전이 여부를 평가하기 위해 시행한 전신 뼈 스캔(whole body bone scan), 양전자방출단 층촬영 $\left({ }^{18} \mathrm{~F}\right.$-fluorodeoxyglucose PET CT)에서 전이는 관찰 되지 않았다. 환자는 수술 후 4개월 동안 총 30회에 걸쳐 5920 $\mathrm{cGY}$ 방사선 치료를 시행하고 종료하였다. 수술 후 8개월째 외래 추적 관찰 중이며, 내시경 소견과 전산화단층촬영상 재 

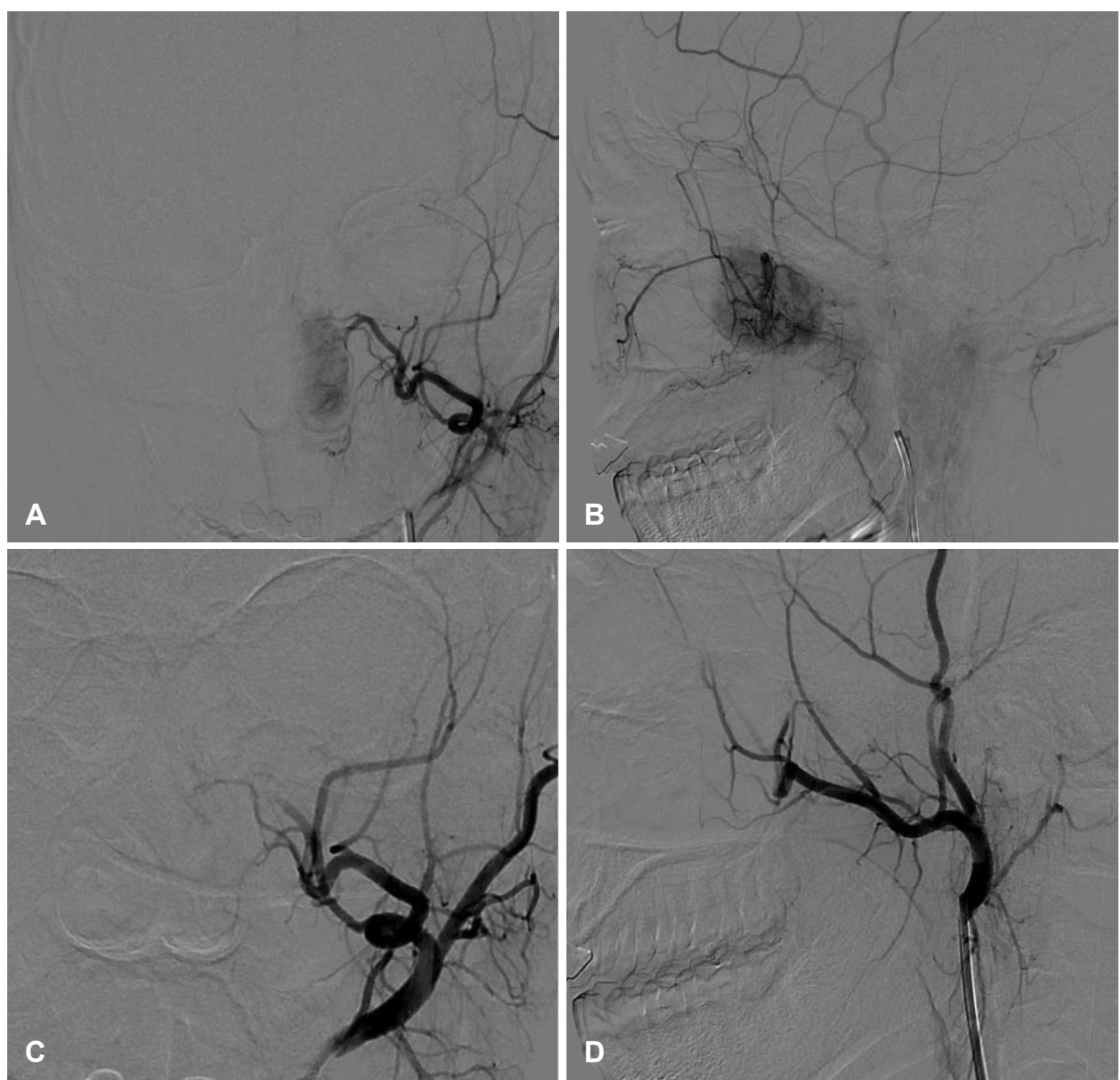

Fig. 4. Left external carotid artery angiography. The tumor blush at the posterior nasal cavity (A and B). After polyvinyl alcohol embolization through internal maxillary artery the tumor disappeared (C and D).

발소견은 보이지 않았다(Fig. 6).

\section{고 찰}

BSNS는 특징적인 병리, 면역조직화학염색 및 paired box 3 gene (PAX3)과 mastermind like protein 3 gene (MAML3) 융합의 발견(PAX3-MAML3 fusion)으로 새로 분류되기 이 전까지 조직학적으로 유사한 섬유육종(fibrosarcoma), 평활 근육종(leiomyosarcoma), 악성말초신경초종양(malignant peripheral nerve sheath tumor), 세포 신경초종(cellular schwannoma), 활막육종(synovial sarcoma)에 포함되어 진 단되어 왔다. 이는 비부비동 내에서 특징적으로 발견되며 ${ }^{1)}$ 주 로 여성에게서 나타난다. Chitguppi 등의 의 연구에 의하면 95명 의 환자 중 남여의 비율은 1:2.27로 여성에서 호발하였고, 진 단 당시 나이는 평균 52.36세(range: 24-87)였으며, 본 증례
의 경우 35 세 여성으로 평균에 비해 비교적 젊은 나이에 발생 하였다. 주로 발생하는 부위는 비강에서 18 건(18.94\%), 부비동 에서 29건(30.52\%), 비강과 부비동 동시에서 29건(13.68\%) 기 원하였으며, 35건(36.84\%)은 기원 미상이었다. 이 종양은 일반 적으로 국소적으로 발생하나 조기에 발견되지 않으면 안면의 구조를 따라서 퍼질 수 있는 침습적인 질환으로, 95건 중 비 부비동을 넘어 침범한 경우는 27 건(28\%)으로 그 중 두개저를 침범한 것은 10 건(37.03\%), 안와를 침범한 것은 12 건(44.44\%), 두개 내로 침범한 것은 4건(14.81\%), 구인두로 침범한 것은 1건 (3.7\%)으로 나타났다. BSNS의 임상증상은 침범 범위에 따라 비폐색, 비분비물, 비출혈, 후각저하와 같은 비증상에서부터 안면통증, 안면 부종과 같은 부비동 침범 증상, 복시, 시야장 애와 같은 안구 침범의 증상까지 다양하게 나타나게 된다.1.4)

$\mathrm{BSNS}$ 의 전산화단층촬영의 특징적인 소견 중 하나는 주변 뼈를 침식하는 것으로 주로 지판(lamina papyracea), 비중격, 

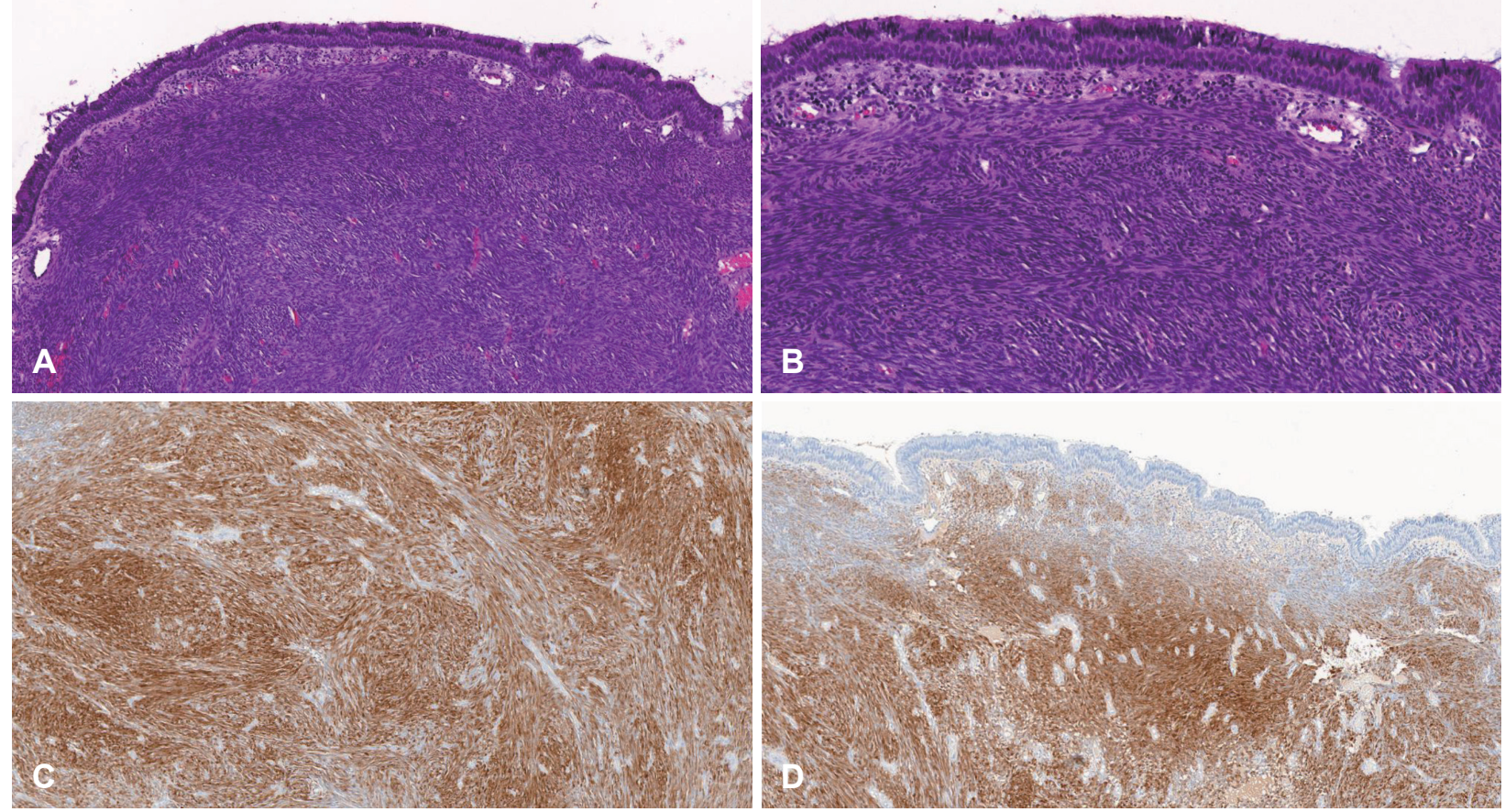

Fig. 5. Histopathological findings. The spindle cells growing and infiltrating with high cell density inside the stroma of the nasal mucous membrane $(A: H \& E, \times 10 ; B: H \& E, \times 20)$. The tumor cells are diffusely immunoreacive for S-100 protein $(C: S-100, \times 10)$ and SMA (D: SMA, $\times 10)$. H\&E, hematoxylin and eosin; SMA, smooth muscle actin.
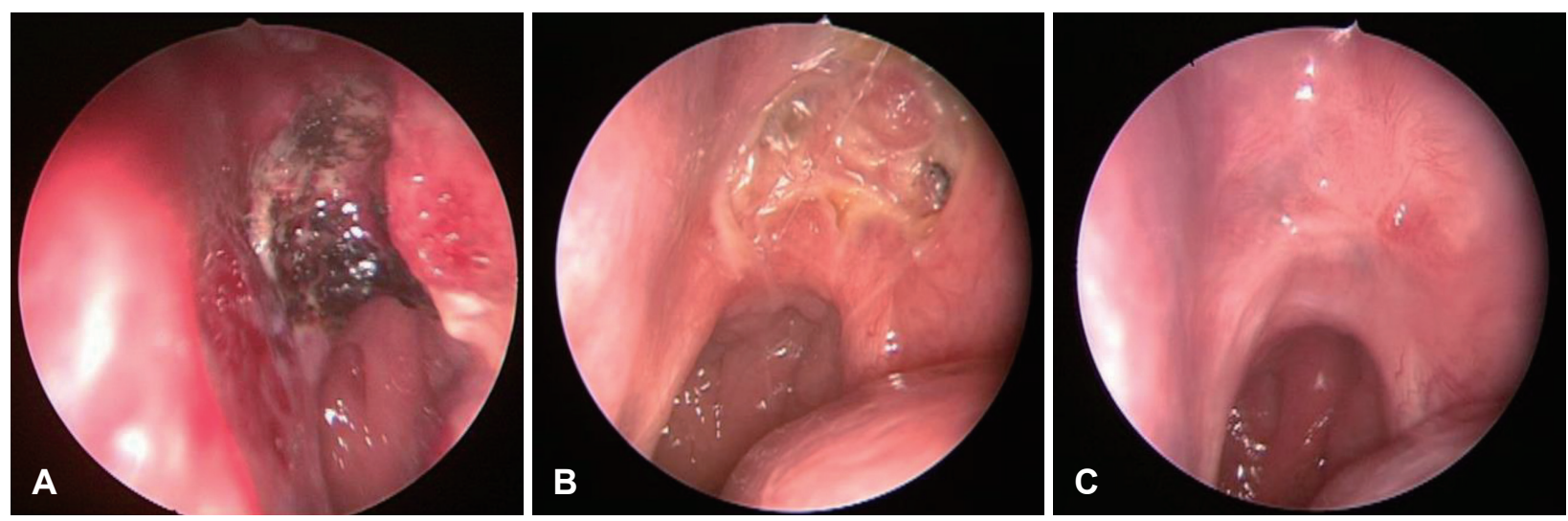

Fig. 6. Endoscopic exam. Postoperative nasal endoscopic findings at left nasal cavity. POD 3 days (A), POD 1 month (B), POD 5 months (C). POD, post operative day.

안와, 두개저부 등의 침범을 볼 수 있다. ${ }^{4,5)}$ 또한 골과다증(hyperostosis)이 두드러지게 나타날 수 있으나, 이는 수막종(meningioma), 양성 비종양, 다른 부비동 악성종양, 염증성 질환 등에도 나타날 수 있다. ${ }^{6-8)}$ 본 증례의 경우 전산화단층촬영상 비강 주변의 다른 구조물의 침식소견은 보이지 않았으며 골 과다증도 보이지 않았다.

자기공명영상은 종양의 안구나 두개 내 침범 범위를 명확히 알 수 있다. 그러나 자기공명영상 중 $\mathrm{T} 1$ 강조영상에서 $\mathrm{BSNS}$ 의 조영증강 패턴은 특징적이지 않다. 그러나 $\mathrm{T} 2$ 강조영상에 서 대뇌 회백질과 유사한 신호를 보여주는 경우가 많으며, 다 른 많은 비부비동 종양보다 낮은 신호를 나타내게 된다. 이는
섬유화된 종양 또는 고도의 세포화된 종양(highly cellular tumor)에서 흔하며, BSNS는 고도의 세포성을 특징으로 하 는 방추 세포 종양(spindle cell neoplasm)으로 이와 같은 특 징을 보이게 된다. 또한 BSNS는 T2 강조영상에서 저강도신 호 및 고강도신호의 불규칙한 배열을 보이는 경우가 많다. ${ }^{5)}$ 본 증례의 경우도 마찬가지로 $\mathrm{T} 2$ 강조영상에서 이질적인 조 영증강(heterogenous enhancement)을 보였다. 그러나 BSNS 는 T2 강조영상에서 균일하게 조영증강(homogenous enhancement)이 되는 경우도 발견되기도 한다. ${ }^{5}$

BSNS의 진단은 조직학적 소견으로 이루어지며, 특히 neural marker인 S-100 protein과 myogenic marker인 SMA에 
대한 면역학적 활성도를 보이고 neural crest differentiation marker인 SRY-related HMG-box 10에 대한 음성을 나타낸 다. 그 외에도 vimentin, $\mathrm{ki}-67$, beta $(\beta)$-catenin 등이 종양을 정확하게 진단하는 데 도움을 줄 수 있다. ${ }^{8)}$ Chandala 등의 연 구에 의하면 S-100 protein은 94건 중 93건(98.93\%), SMA 는 88건 중 82건(93.18\%)에서 양성이 나왔으며, 본 증례를 포 함하여 총 95 건의 검사 결과는 Table 1 과 같다. ${ }^{1-4,9-12)}$ 본 증례 의 환자 또한 S-100 protein, SMA, vimentin, ki-67에서 양 성을 나타냈다.

일반적으로 S-100 protein과 SMA의 발현 등 조직, 면역학 적 소견만으로 $\mathrm{BSNS}$ 를 진단할 수 있다. 그러나 조직학적으로 $\mathrm{BSNS}$ 와 유사하거나 면역학적으로 비전형적인 BSNS의 경우 가 있을 수 있는데, 이는 fluorescence in situ hybridization (FISH)을 통한 PAX3과 MAML3 유전자 재배열의 확인이 필요하다. ${ }^{13,14)} \mathrm{JO}$ 등 $^{14)}$ 의 연구에 따르면 15 개의 $\mathrm{BSNS}$ 증례 및 이와 조직학적으로 유사한 악성말초신경초종양, 활막육종, 방추세포 횡문근육종(spindle cell rhabdomyosarcoma), 고 립성 섬유종, 비부비동 혈관주위세포종(sinonasal hemangiopericytoma), 세포성 신경초종에 해당하는 각각의 10 개 증례를 비교하였다. BSNS에 대한 PAX3의 민감도(sensitivity)는 $100 \%$ (15/15)를 보였으며, 하나의 방추세포 횡문근육 종 증례를 제외하면 위의 다른 모든 종양에서 $\mathrm{PAX} 3$ 는 음성 으로, 그 결과 BSNS에 대한 PAX3의 특이도(specificity)는
98\%로 확인되었다. Chitguppi 등 ${ }^{4}$ 의 연구에 의하면 95건의 $\mathrm{BSNS}$ 중 63건에서 FISH를 시행하였고, 그 중 3건의 실험실 패를 제외하면 PAX3와 MAML3 모두 없는 경우는 4건 $(6.34 \%)$ 뿐이었다.

치료는 종양의 외과적 절제이며 종양의 침범 범위에 따라 두개안면절제술(craniofacial resection)이나 안구 적출술 (orbital exenteration)까지 시행할 수 있으며 외과적 절제 이 후 방사선치료를 추가로 시행할 수 있다. Chitguppi 등ㄴㅇㅢ 연 구에 의하면 치료에 대한 정확한 정보를 알 수 있었던 총 8건 에서 기본적으로 수술적 절제를 하였으며 2건에서 추가적으 로 방사선 치료가 이루어졌다. 치료를 완료한 이후 95건 중 34 건을 평균적으로 4.61년 추적 관찰한 결과, 재발률은 11 건 (32\%)이었으며 재발까지 평균 기간은 2.4 년이었다. 그러나 추 적 관찰한 모든 경우에서 원격전이 소견은 발견되지 않았다. 또한 지금까지 이 종양으로 인해 사망한 경우는 1 개의 증례 밖에 보고되지 않았다. ${ }^{4,8)}$ 그러나 이 예후에 관련한 데이터는 임상적 추적 관찰이 이루어지지 않은 수많은 증례로 인해 제 한적이다. ${ }^{1,48}$ 본 증례 또한 추적 관찰 기간은 아직 8 개월이며 수술한 부위의 재발 및 전이 소견은 보이지 않으나 충분한 관찰 기간이 필요하다.

BSNS는 2017년 발간된 세계보건기구 두경부 종양 분류 4판(the fourth edition of the World Health Organization Classification of Head and Neck Tumours)에 포함되었으

Table 1. Details of immunophenotyping studies

\begin{tabular}{|c|c|c|c|c|c|c|c|c|c|}
\hline Markers/ref & 1 & 2 & 3 & 9 & 10 & 11 & 12 & Case report & Total (\%) \\
\hline S-100 & $28 / 28$ & $3 / 3$ & $7 / 7$ & $1 / 1$ & $42 / 43$ & $11 / 11$ & $1 / 1$ & $1 / 1$ & $94 / 95$ (98.94) \\
\hline SMA & $23 / 25$ & $3 / 3$ & $5 / 5$ & $1 / 1$ & $39 / 42$ & $11 / 11$ & $0 / 1$ & $1 / 1$ & $83 / 89$ (93.25) \\
\hline MSA & $14 / 16$ & $0 / 1$ & $4 / 4$ & & & & $0 / 1$ & & $18 / 21(85.71)$ \\
\hline Beta catenin & & & & & & $10 / 11$ & $1 / 1$ & & $11 / 12(91.66)$ \\
\hline EMA & $3 / 19$ & $10 / 11$ & & $0 / 1$ & & & $0 / 1$ & & $3 / 22(13.63)$ \\
\hline Myo-D1 & & & $3 / 7$ & & $11 / 33$ & & & & $14 / 40(35.00)$ \\
\hline Myogenin/Myf4 & & & $1 / 7$ & $1 / 1$ & $2 / 23$ & $3 / 10$ & $0 / 1$ & & $7 / 43(16.27)$ \\
\hline Desmin & $4 / 20$ & $3 / 10$ & $4 / 7$ & $1 / 1$ & $16 / 36$ & $4 / 11$ & $0 / 1$ & & $31 / 79(39.24)$ \\
\hline Keratin & $2 / 22$ & $4 / 11$ & $2 / 5$ & & & & $0 / 1$ & & $4 / 30(13.33)$ \\
\hline CD34 & $5 / 21$ & & $1 / 5$ & & & & & $0 / 1$ & 6/29 (20.68) \\
\hline sox10 & & $0 / 11$ & $0 / 7$ & & & $0 / 11$ & & & $0 / 18(00.00)$ \\
\hline Vimentin & & & & & & & $1 / 1$ & $1 / 1$ & $2 / 2(100.0)$ \\
\hline h-Caldesmon & & & & & & & $1 / 1$ & & $1 / 1(100.0)$ \\
\hline Factor XIIIa & & & & & & $8 / 10$ & & & $8 / 10(80.00)$ \\
\hline Calponin & & $8 / 10$ & $1 / 1$ & & & & & & $1 / 1(100.0)$ \\
\hline TLE-1 & & & & $1 / 1$ & & & & & $1 / 1(100.0)$ \\
\hline ER/PR & & & & & & & $0 / 1$ & & $0 / 1(00.00)$ \\
\hline Ki-67 & & & & & & & & $1 / 1$ & $1 / 1(100.0)$ \\
\hline CK-Pan & & & & & & & & $0 / 1$ & $0 / 1(00.00)$ \\
\hline
\end{tabular}

S-100, S-100 protein; SMA, smooth muscle actin; MSA, muscle specific actin; EMA, epithelial membrane antigen; SOX10, SRY-related HMG-box 10; TLE-1, transducin-like enhancer of split-1; ER/PR, estrogen receptor/progesterone receptor 
며, ${ }^{15)}$ 본 증례는 국내에서 처음 보고한 증례이다. 지금까지 연 구된 바에 따르면 BSNS는 원격전이의 가능성은 낮지만 높 은 재발률 및 다른 주위 구조물 침범의 가능성으로 철저한 외래 추적 및 관찰을 요한다.

\section{Acknowledgments}

None.

\section{Author Contribution}

Conceptualization: Woo Yong Bae. Investigation: Young Gun Kim, Jae Won Heo. Resources: Young Gun Kim, Jae Won Heo, Song-Hee Han. Writing - original draft: Young Gun Kim. Writing — review \& editing: Woo Yong Bae, Young Gun Kim.

\section{ORCID}

Woo Yong Bae

https://orcid.org/0000-0001-5578-0225

\section{REFERENCES}

1) Lewis JT, Oliveira AM, Nascimento AG, Schembri-Wismayer D, Moore EA, Olsen KD, et al. Low-grade sinonasal sarcoma with neural and myogenic features: A clinicopathologic analysis of 28 cases. Am J Surg Pathol 2012;36(4):517-25.

2) Cannon RB, Wiggins RH 3rd, Witt BL, Dundar Y, Johnston TM, Hunt JP. Imaging and outcomes for a new entity: Low-grade sinonasal sarcoma with neural and myogenic features. J Neurol Surg Rep 2017;78(1):e15-9.

3) Huang SC, Ghossein RA, Bishop JA, Zhang L, Chen TC, Huang HY, et al. Novel PAX3-NCOA1 fusions in biphenotypic sinonasal sarcoma with focal rhabdomyoblastic differentiation. Am J Surg Pathol 2016;40(1):51-9.

4) Chitguppi C, Koszewski I, Collura K, Curtis M, Nyquist G, Rabinowitz M, et al. Biphenotypic sinonasal sarcoma-case report and review of clinicopathological features and diagnostic modalities. J Neurol Surg B Skull Base 2019;80(1):51-8.
5) Miglani A, Lal D, Weindling SM, Wood CP, Hoxworth JM. Imaging characteristics and clinical outcomes of biphenotypic sinonasal sarcoma. Laryngoscope Investig Otolaryngol 2019;4(5):484-8.

6) Lee DK, Chung SK, Dhong HJ, Kim HY, Kim HJ, Bok KH. Focal hyperostosis on $\mathrm{CT}$ of sinonasal inverted papilloma as a predictor of tumor origin. AJNR Am J Neuroradiol 2007;28(4):618-21.

7) Chiu AG, Jackman AH, Antunes MB, Feldman MD, Palmer JN. Radiographic and histologic analysis of the bone underlying inverted papillomas. Laryngoscope 2006;116(9):1617-20.

8) Pieper DR, Al-Mefty O, Hanada Y, Buechner D. Hyperostosis associated with meningioma of the cranial base: Secondary changes or tumor invasion. Neurosurgery 1999;44(4):742-6; discussion 746-7.

9) Wong WJ, Lauria A, Hornick JL, Xiao S, Fletcher JA, MarinoEnriquez A. Alternate PAX3-FOXO1 oncogenic fusion in biphenotypic sinonasal sarcoma. Genes Chromosomes Cancer 2016;55(1):25-9.

10) Fritchie KJ, Jin L, Wang $X$, Graham RP, Torbenson MS, Lewis JE, et al. Fusion gene profile of biphenotypic sinonasal sarcoma: An analysis of 44 cases. Histopathology 2016;69(6):930-6.

11) Rooper LM, Huang SC, Antonescu CR, Westra WH, Bishop JA. Biphenotypic sinonasal sarcoma: An expanded immunoprofile including consistent nuclear $\beta$-catenin positivity and absence of SOX10 expression. Hum Pathol 2016;55:44-50.

12) Powers KA, Han LM, Chiu AG, Aly FZ. Low-grade sinonasal sarcoma with neural and myogenic features--diagnostic challenge and pathogenic insight. Oral Surg Oral Med Oral Pathol Oral Radiol 2015;119(5):e265-9.

13) Wang $X$, Bledsoe KL, Graham RP, Asmann YW, Viswanatha DS, Lewis JE, et al. Recurrent PAX3-MAML3 fusion in biphenotypic sinonasal sarcoma. Nat Genet 2014;46(7):666-8.

14) Jo VY, Mariño-Enríquez A, Fletcher CDM, Hornick JL. Expression of PAX3 distinguishes biphenotypic sinonasal sarcoma from histologic mimics. Am J Surg Pathol 2018;42(10):1275-85.

15) Stelow EB, Bishop JA. Update from the 4th edition of the World Health Organization Classification of head and neck tumours: Tumors of the nasal cavity, paranasal sinuses and skull base. Head Neck Pathol 2017;11(1):3-15. 